Tér és Társadalom 18. évf. 2004/3. 57-75. p.

\title{
A DIGITÁLIS SZAKADÉK, MINT ÚJ PERIFÉRIA-KÉPZŐ JELENSÉG ${ }^{1}$
}

\author{
(The Digital Gap, as a New Phenomenon Responsible \\ for Having Peripheries)
}

SZARVÁK TIBOR

\begin{abstract}
Kulcsszavak:
digitális egyenlótlenségek területi lejtö információs társadalom roma társadalmi csoportok

A tanulmány elméleti és empirikus eredmények tükrében vizsgálja az információs társadalom fejlödéséböl adódó egyenlötlen helyzeteket, a digitális szakadék fogalmát. A téma aktualitäsát az adja, hogy a digitalis téren bekövetkezö társadalmi és területi lejtö a korábbi egyenlötlenségek 2l. századi üjjászületésének tekinthetõ.

Az elemzésben foglalkozunk egy potenciális célcsoport, a romák információs társadalommal kapcsolatos attitũdjeivel, szerepkészletével is. A roma társadalmi csoportokkal készült kérdöives vizsgálat adatai alapján sürgetjük azt, hogy a földrajzi periférián élö társadalmi csoportok számara induljanak a helyi igényeknek megfelelö digitális e-esélyegyenlöség politikák.
\end{abstract}

A globalizációs folyamatok bonyolult társadalom és területszervező hatásai és az ezzel párhuzamos technológiai innováció differenciált környezetet, komplex életvilágot „kényszerítettek” a modernitás emberére. A 20. században a biztonság iránti (ősi) vágy kielégítése, a tájékozódás (már zömmel) közvetett információk révén történhetett meg. Az info-kommunikációs eszközök terjedése és a hálózaton meginduló hihetetlen mértékủ információáramlás új társadalmi paradigmát, az információs társadalom típusú fejlődés útját rajzolta ki.

A különböző információs társadalom definíciós kísérletek (Castells 1996; Kasvió 1999; Varga 1999; Dessewffy 2002; Z. Karvalics 2002) megegyeznek abban, hogy az életvilág különböző szintjeire beépülö múszaki-technikai háttér „,csak” a korai adaptációs szakaszra jellemző, ezért szükséges és elégséges feltétele az információs társadalom terjedésének.

Az információs társadalom típusú fejlödés fogalmi keretének kialakítása során azokat a dichotóm (input-output) közvetítő elemeket kell megtalálnunk, amelyek a paradigma rendszerjellegét jelenthetik. Úgy gondoljuk, hogy a társadalmi szférák között meghatározható egyenlőtlenség-párok egyrészt rávilágítanak a technológia által meghatározott kor társadalmi rendszerelméletére (Pokol 1988), másrészt átvezetnek bennünket a csendes forradalom ${ }^{2}$ rétegképzö mechanizmusainak, az információs társadalom egyenlőtlenségeinek vizsgálatához ${ }^{3}$.

A 21. század első évtizedében az a kérdés, hogy az információ birtoklás és használati tudás lehetöséget biztosít-e (a hagyományos kulturális tőkéhez hasonlóan) a tőketranszformációra. Mivel a különböző tőkefajták egymáshoz való kapcsolódását a társadalmi-területi egyenlötlenségi rendszer határozza meg (Kolosi 2000), fontos megnéznünk, miként jelentkezik a hagyományos egyenlötlenségi mechanizmus az 
információs korban. A digitális tőke egyenlösít-e (ahogyan az IT teoretikusai remé${ }^{l i k}{ }^{4}$ ), vagy - legitimációs alappá, érdemmé válva (Kolosi 2000) - tovább szélesíti, felerősíti a társadalmi-területi különbségeket?

\section{A digitális szakadék fogalmának története, konceptualizációjának néhány kérdése}

Bár a digitális szakadék körüli vélemények megjelenése egyidős az információs társadalom kialakulásával, az eredeti digital divide fogalmat elöször az újságírói és politikai közbeszédben a múlt évtized közepén használták az Egyesült Államokban (Molnár 2002). A fogalom betörése a közéletbe a csekély info-kommunikációs diffúzió miatt váratlan volt, de nem volt elméleti elözmény nélkül, mert már az Unesco kiadásában megjelent klasszikus McBride jelentés is szólt a tanulmány címében is rögzített dilemmáról, hogy a komputerizáció növelheti-e a demokratizációt, és csökkentheti-e a különbségeket a társadalmi csoportok között.

Úgy véljük, hogy a kilencvenes években az ilyen irányú diskurzus felerősödése az Egyesült Államokban az akkori demokrata kormányzat harmadik utas társadalomfejlesztő programjához kapcsolódik. Egy tartalomelemzéses vizsgálatból ugyanis kitủnt az, hogy ezen baloldali politikai irány központi fogalmai között föként a témánkhoz tartozók szerepelnek ${ }^{5}$ (G. Márkus én.).

$\mathrm{Az}$,új közép” társadalompolitikai elvéhez elengedhetetlen a „digitális szakadék” szükítését célzó különböző állami stratégiák alkalmazása. Az egyik legutóbbi kormányzati pályázat ${ }^{6}$ így fogalmaz: „A támogatás célja, hogy elősegítse a társadalmi versenyképesség javulását, az e-demokrácia kiteljesedését, lehetövé téve az állampolgárok számára, hogy az információs társadalom nyújtotta lehetöségekkel széles körben élhessenek""?

Az OECD 2001-es definíciója szerint a digitális szakadék fö jellemzője az a hozzáférés, ami az egyének, a háztartások, a gazdasági és földrajzi területek között létezik, s amelyet különbözö társadalmi gazdasági változók határoznak meg.

Mások szerint (Hïsing 2003) a politikai diskurzus (természeténél fogva) leegyszerüsít, mert az információs társadalomban lévö esélyekröl és veszélyekröl jó ideje csak jelszavakban, a digitális szakadék szintjén beszél.

A digitális szakadék hasonlata nem más, mint a társadalmi harmóniára, igazságosságra (konfliktusmentességre) való törekvés: növelni kell a társadalmi-területi bevonódást (e-inclusion) az info-kommunikációs eszközök használatába.

Különösen az EU területén hangsúlyozzák az e-bevonódást politikai célként ${ }^{8}$. Az e-inaktivitás ugyanis szükíti a piacot és veszélyeztetheti a közéleti participációt.

A digitális szakadék fogalmi párról számos szerző (Paul DiMaggió és Hargittai Eszter, Dessewffy Tibor, Z. Karvalics László) úgy vélekedik, hogy az internetpenetráció olyan szinten van már (föként az USA-ban!), hogy szakadék helyett érdemesebb a digitális egyenlötlenség fogalmát használni.

Mi ezzél szemben úgy véljük, hogy Magyarországon ez a technikai hozzáférés még elég alacsony szintủ ahhoz, hogy ne használhassuk ezt a fogalmat, bár a társadalom- 
tudományi közbeszédben - a hagyományos és a digitális hátrányok összehasonlíthatósága érdekében - az egyenlötlenségi dimenzió kiemelése javasolt.

Dessewffy Tibor és Z. Karvalics László (2002) szerint négy meghatározott relációt hordozó területi-társadalmi egyenlötlenségi kategóriával kell szembenéznünk ahhoz, hogy eséllyel robogjunk az információs szupersztrádán. Ezek a kategóriák az információs társadalom fenntarthatóságát, az adott (lokális) társadalom humán „kapacitását” befogadó - adaptációs - készségét, innovativitását, mozgósítható, konvertálható tudását és anyagi tőkéjét jelentik.

A materiális kategória a ,pénzügyi hozzáférést” az info-kommunikációs eszközök mủködtetésének anyagi korlátait vagy szabadságát jelenti. A „kognitív hozzáférés” jelenti azt a KRESZ-ismeretet, az e- és hagyományos kulturális tökét, amely képessé teszi az egyént, illetve a közösségeket a hálózati információszerzésre.

A ,tartalmi hozzáférés” a kínálati piacot jelenti. Másként fogalmazva: ha nincs a hálón olyan üzenet (tartalom), ami érdekli a felhasználót, a World Wide Web nem lesz az, amilyennek az információs kor teoretikusai álmodták. A negyedik kategória a politikai alrendszer szintje. Ennél a makro tényezönél az a fontos, hogy mennyire erős a szféra szándéka az új médium ellenőrzésére.

A Szociológiai Társaság 2002-es konferenciáján megrendezett információs társadalom témájú szekcióban Dányi Endre és Dessewffy Tibor előadásában elhangzottak szerint a digitális szakadék metafora leegyszerüsítỏ dichotómia. Nem vizsgálja ugyanis a digitális egyenlőtlenség összetett viszonyait. „A digitális szakadék fogalmából nem derül ki, hogy hol és kinek a legrosszabb, vagyis, hogy hol és milyen jellegủ beavatkozásra volna szükség." (Dányi-Dessewffy 2002) Ebben a kontextusban a cselekvés fontossága, a cselekvő személy másodlagos. Nem tudjuk meg, pl. milyen előnyök adódnak az adott társadalmi csoportnak a hálózati tudásból, az informatikai kultúrából, és nem ismerjük azt sem, hogy egyáltalán lenne-e igénye az adott csoportnak átkerülni a szakadék másik oldalára. A szerzöpáros szerint ennek az az oka, hogy a fogalom statikus jellegü. Középpontjában a szakadék léte és az információs társadalomban való klasszikus (középosztály centrikus) magatartásminták állnak.

Kérdés, hogy a digitális szakadék ,,csak” szélesíti-e a hagyományos egyenlőtlenségek skáláját és újabb (információs kori) polarizációt jelent, vagy inkább az információs társadalom jellemzőjének megfelelően, az egyenlőtlenségek teljes átrétegzödésének és egy egészében új társadalmi egyenlötlenségi rendszer születésének vagyunk-e a tanúi. Társadalom- és területpolitikai szempontból az a kérdés, hogy a digitális szakadék kíván-e újfajta fellépést, paradigmaváltást, vagy elégséges a digitális szakadék bizonyos szintủ-mélységủ kezelése, és nincs szükség az átfogóbb vizsgálatára, mert egyrészt úgysem lehetséges a megszüntetése, másrészt tőle függetlenül és sokkal fontosabb társadalmi egyenlőtlenségek is léteznek (Pintér 2003).

A digitális szakadék fogalmát számos tanulmány (pl. Rodriguez-Wilson 2002; Hüsing 2003) összetett módon, az info-kommunikációs produktumok, az outputok (pl. számítógép, internetes hálózatok, mobil kommunikáció stb.) és az inputok (tudások, felhasználók stb.) függvényében tárgyalja. Véleményük szerint hét kategóriában 
(faj, nem, életkor, képzettség, jövedelem, lakóhely, fogyatékosság) lelhetők fel szignifikáns küilönbségek az info-kommunikációs eszközök használatában".

Mások szerint (pl. Norris 2001) a digitális szakadék három területet ölel fel: az információs korban globális, szociális és demokratikus egyenlötlenségi helyzeteket találhatunk. Fontos megállapítása még az, hogy az info-kommunikációs eszközök használatában mindig lesznek különbségek a résztársadalmi csoportok között. Ezért beszélnek jelenleg inkább Mercedes divide-ról: mindenki szeretne Mercedest, csak sokan nem engedhetik meg maguknak - ellenben autót bárki vehet, elérhető áron kapható. Vagyis, hogy az internetezés terén sem lesz egyenlőség a társadalomban, és végeredményben az egyenlötlenségek újratermelödnek (Pintér 2003).

A ,digitális szakadék” fogalmát mások (Zapf [2002a] és bizonyos szempontból Fukuyama [2000] is) ,kulturális szakadéknak/résnek” is tartják. A technológiai változások generálta innováció ugyanis leggyorsabban a gazdasági alrendszert interiorizálhatja. S mivel a társadalmi intézmények lassabban változnak, a modern információs korszak technológiai újitásainak adaptációja föként kulturális vonatkozású.

A digitális szakadék fogalom konceptualizációja az innovációk terjedésének elméletét sem nélkülözheti. Rigler András A digitális szakadék tágulásának modellje címú előadásában ${ }^{10}$ elmondott diffúziós folyamat kezdetekor az informatikával való foglalkozás teljes mértékben professzionális tevékenységnek számított. Ekkor még nem volt értelme digitális szakadékról beszélni. A második korszakban az informatika kitört a professzionalizmus burkából, de - egyelöre csak kevesek számára vált elérhetővé. Még mindig főként munkaeszköz volt a számítógép. A harmadik szakaszban egyre szélesebb rétegek számára válik elérhetővé az informatika, végül a negyedik szakaszban megjelennek azok az alkalmazások, amelyek a mindennapi életben is hasznos segítötárssá, némely esetekben nélkülözhetetlenné teszik a számítógépeket és az internet nyújtotta lehetőségeket.

\section{Két területi-társadalmi út: az információs társadalom a periféria esélye, vagy ,a szegény országok elvesztik az információs forradalmat"? "I}

Mivel korunk modernizációs hullámában az info-kommunikációs technológiáknak hatalmas szerepük van, egyre inkább beszélhetünk a hagyományos innovációs lánc (út) megfordulásáról. A technológia teremtette új alkalmazások növelik az esélyegyenlöségi közpolitikák mozgásterét, és erősítik az e-bevonódás folyamatát. Ez a modernizációs trend relativizálhatja a különbözö térfogalmakat . A központnak nem az lesz a feladata - írja Farkas János (2003), hogy megmondja ki lesz a központ, hanem be kell csatornáznia az alulról induló kezdeményezéseket. A hálózati forradalom - mivel nem centralizáltan hat - jó lehetőség arra, hogy a perifériák mozgása, aktivitása megjelenjen a „makro" társadalomban. A perifériák - technológiai innovációból is adódó - szerepváltozása jól kapcsolódik a regionalizációs folyamatokhoz, a központi állami beavatkozó feladatok lebontásához: 
„A regionális követelések nem mások, mint a stigmatizációra adott válasz, amely megteremti azt a területet, amelyből látszólag ered" - mondja Pierre Bourdieu (idézi Bỏhm 1999, 217).

És mi jellemzi ezt a ,,megbélyegzett teret”? A főváros (a központ) által konstruált anyagi és szimbolikus tökétől való megfosztottság, egyfajta speciális - társadalmi gazdasági távolság.

A digitális szakadék területiségének vizsgálatakor a kulcsszerzőktöl (Ady Endre, Vitányi Iván és Szücs Jenö) a hagyományos történeti fogalmak jutnak eszünkbe: kompország, szervetlen fejlödés és ebböl következöen a nyugati és a keleti fejlödési modell közé eső régió. A hagyományos egyenlötlen helyzetek fennmaradása erösítette azt, hogy a digitális szakadék (az információ-gazdagok és az információszegények között) az utóbbi években széles körben elterjedt. Hatásában akár a kockázati társadalom fogalmi készletéhez (a megfelelés, az adaptáció igényének, a lemaradástól való kollektív félelemnek) is kapcsolhatjuk. Dányi Endre és Dessewffy Tibor (2002) szerint a kelet-közép-európai térség szempontjából az elkövetkező 3-4 év jelentősége az, hogy az itteni országok a nagy óceán melyik partjára kerülnek a digitális világ térképén. Vagyis a felzárkózás és elkésődés dichotómia (egyfajta közép-európai vagy magyar identitásként) az információs társadalomban is megmarad.

A perifériák esélye azonban összességében a sokat emlegetett fenntartható, szerves fejlödési útban rejlik, mert néhány társadalomkutató (pl. György Péter, Tamás Pál) szerint a globalizáció nem kedvez az oly sokat emlegetett társadalmi közép kialakulásának, mert gyorsan emel fel, illetve süllyeszt le társadalmi rétegeket. Úgy gondoljuk, hogy ez a dinamikus változás a területiségben is hasonlóképpen tapasztalható, ezért fontos Pippa Norris megállapítása, miszerint a lokális fejlesztési munkának a helyi viszonyokra reagálva kell kompatibilisnek lennie a globális technológiával (Norris 2001). Az innovációs lánc (Pokol 1988) továbbvitele miatt mindenképpen szükséges a megfelelő területi szinthez kapcsolódó információs társadalom program elkészítése, mert további leszakadás (és ezzel szociális konfliktus is) következhet be a határozottabb szándékot felmutató és hosszabb távon gyorsabb fejlödésre képes térségektől.

A nemzetközi digitális szakadék elemzések (pl. Rodriguez-Wilson 2002; Hüsing 2003) fontos megállapítása az, hogy az info-kommunikációs technológiák adaptációjában (a folytatódó modernizáció miatt) a szegény országok is fejlődnek, de az információs társadalom korszakában is létező verseny tovább növeli a különbségeket.

A perifériák esélyeit rontja, hogy a hálózati társadalom ,lelkét” jelentö múszakitechnikai hálózat telepítését a gazdaság törvényszerủségei (megéri/nem megéri) határozzák meg ${ }^{12}$ (Kanalas 2000), az infrastruktúra így önmagában is megosztja a társadalmat és a teret. Telepítése (általában) együtt jár az információs (és tudás) társadalomhoz kapcsolódó adaptív-innovatív képességek eröteljesebb társadalmi jelenlétével.

A társadalmi-területi felzárkózás tartósságához úgy gondoljuk az (is) kell, hogy biztosítsuk (vagy legalább bemutassuk) a társadalmi-gazdasági „,main stream”-hez való csatlakozás előnyeit. A 21. században a különbözö vidékfejlesztési politikák alapvető kérdése ugyanis az lesz, hogy bekapcsolhatók-e a résztvevők (és családjaik) 
a nagy társadalmi folyamatokba, vagyis a lokális erőforrásokra alapozva kialakíthatók-e a települési információs társadalom alapjai. Úgy véljük, hogy ezek az irányok felértékelhetik a helyi humán eröforrásokban, a gazdasági és a tudásalapú modernizációban rejlö lehetöségeket, vagyis növelhetik a térség megtartóerejét, hiszen az új technológiára leginkább a fiatal (felnőtt) korosztály nyitott.

Ez a stratégia a technikai innováció általános használatához elengedhetetlen társadalmi innováció meggyökeresítését segítheti (Zapf 2002a). A társadalmi innovációk új életstílusokat jelentenek, amelyben (Robert K. Merton fogalmi rendszerét idézve) az elismert/elfogadott célok eléréséhez új eszközöket alkalmazunk. Ha ez a minta nem terjed el a társadalmi csoportokban (vagyis ellentmondás lesz a célok és az eszközök között), anómiás, társadalmi konfliktusos helyzet alakulhat ki.

Persze nyilvánvaló, hogy az emberiség egésze nem léphet be egyszerre az információs korszakba, miként az egyes lokális társadalmak is csak kisebb vagy nagyobb részben kapcsolódtak a földet behálózó kapcsolati körbe (Csepeli 2002), mégis a társadalompolitikának tenni kell azért, hogy az információhoz való hozzájutás alapjog (később pedig alapigény) legyen. A megvalósításban normatív elképzelések is felmerültek (Szarvák-Szoboszlai 2003), de jelenleg az egyik (megvalósítható) elképzelésnek a közösségi hozzáférési pontok számának növelése tünik.

\section{Miért kellenek az e-esélyegyenlöség politikák ${ }^{13}$ ?}

Az info-kommunikációs eszközök további elöretörésének következtében bekövetkezett-bekövetkezik a magán, a köz és a gazdasági élet majdnem minden területéhez való hálózati hozzáférés. Ebböl adódik az a gondolat, hogy az infokommunikációs eszközökkel való bánásmód elengedhetetlenül fontos feltétele (lesz) a társadalmi bevonódásnak.

A fogyasztói magatartáson túl az info-kommunikációs eszközök terén való jártasság - már jelenleg is egyre inkább - feltétele az aktív foglalkoztatási státusznak. Az ilyen típusú tudásból következhet az, hogy a foglalkoztatottsági arányban megjelennek az info-kommunikációs technológia szélesebb használatából adódó pozitiv hatások ${ }^{14}$.

Ezen kívül az e-kormányzattól és más info-kommunikációs technológia által támogatott állami szolgáltatóktól, főként az egészségügy és az oktatás területén, a várt takarékossági potenciál csak akkor jelentkezik, ha a lakosság többségének van hozzáférése és tudja is használni az info-kommunikációs eszközöket. Harmadrészt egyre több magángazdasági szolgáltatást kínálnak online a mindennapi élethez (is) kapcsolódóan. Összességében az is elmondható, hogy a mindennapi élet költségei azok számára nőnek, akik semmilyen hozzáféréssel vagy jártassággal nem rendelkeznek az info-kommunikációs technológiák terén (Hüsing 2003).

Úgy véljük, hogy a fenti folyamatokban való részesültség és produktivitás kialakíthatja az egyénben a racionális magatartást, cselekvéstípust, amely számos klaszszikus (Max Weber, Jürgen Habermas, Pierre Bourdieu stb.) szerint feltétele a különböző mobilitási pályákon való elindulásnak, a folytatódó modernizációnak (Zapf 2002b), melynek egyik mai kihívása az információs társadalom típusú fejlődés. 


\section{A digitális szakadék mérésére szolgáló indexek ${ }^{15}$}

A digitális szakadék index létrehozása azt szolgálja, hogy az EU-tagországok körében lévő e-bevonódás állapotát összehasonlíthassuk ${ }^{16}$. Az ilyen módszerű indexkészítés elönyének számít az, hogy számolhatunk az info-kommunikációs technológia adaptációjában rejlő, nemzeteken belüli szociális egyenlötlenségekkel is.

$\mathrm{Az}$ indexkészítés hipotetikus célja az, hogy magyarázzák-e a terjedési teóriák ${ }^{17}$ az info-kommunikációs technológia használatában lévỏ empirikusan megállapítható különbségeket a vizsgált társadalmi csoportokban és a részt vevỏ országokban. A diffúziós elméletek alapján feltételezhetjủk, hogy a hátrányos helyzetü társadalmi csoportok és területek, valamint a lakossági átlag közötti távolság elöször megnövekszik. Az e-társadalmi távolság akkor csökken, amikor kirajzolódik széles tömegek számára egy piaci telítettségi határ ${ }^{18}$.

A négy vizsgált csoportban való elterjedés alacsonyabb szintủ növekedést mutat, mint a lakosság egésze körében ${ }^{19}$. Az Internet-alkalmazók aránya az alacsonyabb iskolai végzettségú válaszadók körében 1997-2002 között 1\%-ról 12\%-ra, a PC használat ebben a csoportban 13\%-ról 17\%-ra nött, mialatt a megfelelő értékek növekedése az összlakosság Internet és számítógép használatában jóval intenzívebb volt. A terjedés majdnem minden kategóriában egy $\mathrm{S}$ görbe alsófelét írja le.

Érdekes, hogy az európai szint együttes digitális szakadék indexe alig változott. $\mathrm{Az}$ alcsoportok (főiránytól) ellentétes fejlödése kiegyenlítette a növekedést. A információs társadalomban klasszikusan élenjáró országok - az északi országok, Hollandia, illetve Anglia -, továbbá Ausztria, Írország, amelyek gyors infokommunikációs boomot éltek meg a közelmúltban, javították az e-bevonódást. Ez azonban nyilvánvalóan jelentósen növelte a dél-európai országok lemaradását az info-kommunikációs terjedésben.

A társadalmi kategóriák között elmondható, hogy a nemek között már nem mutatható ki jelentősebb kapcsolat az info-kommunikációs eszközök használatában, bár a férfiak még mindig erősebb használati intenzitást mutatnak. A női info-kommunikációs használati index 80-ról 87 pontra növekedett az EU tizenötök körében. Fontos megemlítenünk, hogy a 2002-es európai értékek - 62 pontos görög és 96 pontos finn eredmények - közötti nagy szóródás jelentős eltéréseket feltételez a nemek közötti esélyegyenlőségben. Az idősek körében az info-kommunikációs használat nem mutatott egységes képet. 2000-ben még úgy festett, mintha az 50 évnél idősebb polgárok már erösebb használati értéket mutatnának, de végül a 2002-es survey értékei újra csak az 1997-es felmérésben tapasztaltakhoz közelítettek. Az alacsony jövedelmi kategóriájú társadalmi csoportok körében a használat értékei az 1997-es vizsgálatban rögzített adatok alatt rendeződtek. Azon személyek körében, akik az iskolát 15 éves korukban vagy azelött hagyták abba a használati ráta az egész lakosság 30\%-a kỏrül stagnált az elmúlt 6 évben.

Látható, hogy az alacsony iskolai végzettség által determinált tudás- és attitűdkészlet, valamint az alacsony jövedelmi viszonyok meghatározzák azt, hogy az 
egyén az info-kommunikációs használat terén a digitális szakadék melyik oldalához kapcsolódhat.

A gazdag, élenjáró országok csekélyebb szociális egyenlötlenségekkel bírnak, mint a szegényebb dél-európai lemaradók. De azok az országok, amelyek késtek az info-kommunikációs felzárkózásban, szintén nagyobb társadalmi egyenlőtlenségekkel voltak jellemezhetők. A technológiák földrajzi-társadalmi diffúziójának szabályozottságára utal az a megállapítás, amely szerint az elterjedés az ún. korán adaptáló országok hátrányos helyzetü régióiban később történik meg, mint a központi, illetőleg a gazdaságilag erós régiókban, ugyanakkor ezen társadalmi-területi csoportok technológiai adaptációja - valószínüleg a mintakövetés miatt - összehasonlíthatóan gyorsabban megy végbe (fejlódik).

Összességében elmondható, hogy az IKT-használat növekedése konstans értékkel, valamint a hátrányos helyzetủ társadalmi csoportok állandó vagy csökkenő részvételével jellemezhetö az Európai Unió országaiban. A hátrányos helyzetủ csoportok, amelyek a lakosság átlag használati szintjét hosszabb idő alatt érik el, információs társadalmi átlagos részvétele Svédországban az összlakosság 65\%-ára, Portugáliában 27\%-ára tehető. Ebben az indexben Svédország (Ausztria, Dánia, Hollandia, Anglia, Hollandia, Írország, Finnország ${ }^{20}$ ) éllovasként, Németország átlagos országként, Portugália lemaradó államként szerepel.

Azon EU-tagállamokban, amelyek egy bizonyos info-kommunikációs terjedési szintet később érnek el mint mások, az info-kommunikációs eszközök használatában erősebben érvényesülnek a társadalmi-területi egyenlötlenségi változók. Az idézett tanulmány két fontos megállapításában a hagyományos (észak-déli lejtő) megmaradását és a digitális szakadék megmaradását prognosztizálja.

\section{Információs társadalom modellek az újonnan (2004-ben) csatlakozott országokban}

A már idézett SIBIS felmérés alapján látható, hogy a kelet-európai belépö országok digitális szakadék indexe a tizenötök átlagának feléhez közelít. Megjegyzendő, hogy néhányuk (Észtország, Csehország, Lengyelország, Szlovákia, Szlovénia) a tagjelölt országok átlagánál magasabb értéket ért el.

Az info-kommunikációs technológia használatának polarizációját jól jellemzi az, hogy az átlagnál magasabb digitális szakadék indexértékkel az EU magállamaihoz tartozó Franciaország is a tagjelölt csoport közé került. A (volt) tagjelölt országok átlagánál alacsonyabb digitális szakadék indexértékkel rendelkezik az EU-tagországok közül Belgium, Spanyolország és Olaszország. Mindezek mellett a 2004 májusában taggá vált Litvánia, Lettország és Magyarország is ebbe a csoportba tartozik.

Érdekes, hogy a leszakadók közé került a csatlakozásra váró Bulgária és Románia, valamint két, már tagország, Görögország és Portugália is.

Ebből a digitális szakadék index-térképböl az információs kor szigetszerüen innovatív gócpontjai és a hagyományos periféria irányok (észak-déli és nyugat-keleti lejtö) rajzolódik ki, amely új jellemzöket adhat a területi fejlödésnek Európában. 
Az információs technológiák meggyökeresedésében a korábbi történeti példák köszönnek vissza Közép-Európában. A keletet nyugattól egykoron elválasztó, Szủcs Jenő által vázolt törésvonal, köztes régió áthalad a visegrádi országokon és hatását ma is érezteti, ezért lehet egy közép-európai mag, a visegrádi információs társadalmi modellről beszélni (Pintér 2003).

Ugyanakkor fentebb láttuk, hogy több ország-csoport is más-más fejlődési utat követ az információs társadalom terjesztésében. Egy összehasonlító GDP felmérés alapján elmondható, hogy Lengyelországnak, Szlovéniának, Szlovákiának, Magyarországnak, Csehországnak (és Macedóniának) a bruttó nemzeti össztermék értéke haladta meg vagy érte el a rendszerváltás korit (Farkas 2001 - idézi Pintér 2003). Ezek az országok a digitális szakadék index európai összehasonlításában a középmezőnyben, a követök csoportjában helyezkednek el.

A Magyarországon tapasztalható információs társadalomfejlődés nem sorolható egyértelmúen tisztán üzleti, illetve a jóléti (egyfajta közpolitikai) kategóriába. Mivel ez a modell is egyre inkább a globális információs társadalomban kapja meg a maga helyi értékeit és keretét (Pintér 2003), érdemes alaposabban megnéznünk néhány empirikus adatfelvétel alapján, hogy milyen területi-társadalmi jellemzöi vannak Magyarországon a digitális szakadéknak.

Egy ilyen irányú indexépítésre alapuló törekvés Kanalas Imre munkájában lelhető fel, aki megállapította, hogy azokon az új, s a területi fejlődést is leginkább dinamizáló területeken (felsőoktatás, kutatás-fejlesztés, informatikai infrastruktúra és alkalmazások, magas szintü üzleti szolgáltatások, IKT vállalkozások stb.) a legnagyobb a megyék közötti ellătottsági és fejlettségi különbség, amelyek nemcsak a nemzetközi, de a hazai környezetben is a hosszú távú területi versenyképességet legnagyobb mértékben befolyásolják ${ }^{2 !}$ (Kanalas 2003).

\section{A digitális szakadék területi-társadalmi jellemzői néhány empirikus felmérés tükrében}

A digitális egyenlőtlenségek pontosabb felvételére nagymintás, kisebb területi egységre vonatkozó információs társadalom vizsgálatok még nem terjedtek el, a speciális területi-társadalmi hátrányok a World Internet Project magyarországi kutatási jelentéseiben ${ }^{22}$ (Rigler én.) kevésbé szembetủnőek. Bár Csepeli György (2002) úgy véli, hogy a cezúra a városi és a falusi lakóhely között húzódik. A falvakban élők ma még szinte áthághatatlan akadályokkal számolhatnak, ha részeivé kívánnak lenni a hálózat világának.

A Word Internet Projekt tavalyi hazai adataiból kiderült, hogy a magyarországi háztartások 26\%-ában volt legalább egy számítógép; ez a 2001-ben mért 22\%-os elterjedtséghez képest 4\%-os növekedést jelent. A számítógép-ellátottság növekedésének üteme 2002-ben azonban lelassult: míg 2001-ben az előző évhez képest 29\%-kal több háztartásban volt személyi számítógép, a 2002-es ellátottság 2001 -hez képest már csak 14\%-kal volt magasabb (Dessewffy-Fábián 2002). 
A digitális szakadék létét jól jelzi az, hogy a háztartások személyi számítógéppel való ellátottsága régiónként jelentős különbségeket mutat. Az átlagosnál magasabb a számítógéppel rendelkező háztartások aránya a Budapest környéki agglomerációban, és viszonylag magas a Dunántúlon is. A legkisebb arányban az alföldi háztartásokban található számítógép. Ugyanakkor éppen a Dél-alföldi régióban mérhetó az egyik legdinamikusabb bỏvülés: az itt mért 19\%-os ellátottság a 2001-es arányhoz képest 34\%-os növekedést jelent, ilyen mértékủ növekedés ezenkívül csak a Közép-Dunántúlon tapasztalható (Dessewffy-Fábián 2002).

A 2001-es WIP (World Internet Project) adatbázisból alkotott info-kommunikációs otthoni hozzáférési index alapján a Közép-magyarországi és a Nyugat-dunántúli régió relative jobb helyzete jelezhető. Erősen leszakadó területnek az Alföld számított, a köztes, az info-kommunikációs használatot követö földrajzi térségekhez a Dunántúl egyéb területei és az Észak-Magyarország tartozott (Fábián 2002)23. (I. táblázat).

Ha a reprezentatív lakossági felmérésből alkotott területi értékeket összehasonlítjuk egy ún. prominencia felmérés ${ }^{24}$ (Szarvák 2001) adataival is, akkor azt látjuk, hogy az ország hét régiója közül az információs társadalom fejlödése szempontjából legelőnyösebb helyzetben lévönek a válaszadók (a területfejlesztési partnerkapcsolatok szereplöi) a közép-magyarországit és a nyugat-dunántúlit gondolták.

Bár a kỏzép-magyarországi alminta - ellentétben a nyugat-dunántúli válaszadókkal - a régió vezető helyét nem találja egyöntetünek az információs társadalom kiépülése szempontjából, mert - vélhetỏen Pest megye eltérő társadalmi-gazdasági fejlödéséből következően - a lehetséges ,helyezési” értékek (1-7) szórása a maximumot mutatja.

\section{TÁBLÁZAT}

Digitális szakadék méröszámok összehasonlítása régiónként, 2001

(Comparison of Digital Gap Indices by Regions, 2001)

\begin{tabular}{lccc}
\hline & $\begin{array}{c}\text { Háztartások } \\
\text { számítógép } \\
\text { ellátottsága (\%) }\end{array}$ & $\begin{array}{c}100 \text { fokú info- } \\
\text { kommunikációs } \\
\text { hozzáférési index }\end{array}$ & $\begin{array}{c}\text { Szubjektív in- } \\
\text { formációs társa- } \\
\text { dalom fejlettségi } \\
\text { attitüd értékei } \\
(1-7, \text { átlagok) }\end{array}$ \\
\hline Közép- & 30 & 51 & 2,69 \\
Magyarország & 24 & 50 & 2,72 \\
Nyugat-Dunántúl & 20 & 45 & 3,33 \\
Közép-Dunántúl & 20 & 44 & 3,96 \\
Dél-Dunántúl & 17 & 41 & 4,72 \\
Észak- & 14 & 38 & 4,18 \\
Magyarország & 16 & 36 & 5,50 \\
Dél-Alföld & Észak-Alföld & &
\end{tabular}

A 2001 őszén lebonyolított prominencia vizsgálatban a területfejlesztési szereplök (regionális fejlesztési tanácsok tagjai, regionális fejlesztési ügynökségek vezetöi, megyei területfejlesztési tanácsok elnökei, kistérségi megbízottak, kistérségi menedzserek) 32\%-a küldte vissza kérdöívünket.

Forrás: Szarvák 2001; Dessewffy-Fábián 2002; Fábián 2002 alapján. 
Átlagos fejlettségü régiók közé a dél-dunántúli és a dél-alföldi területek sorolhatók. Az átlagostól rosszabb helyzetben volt az Észak-alföldi és az Észak-magyarországi régió. A hátrányos helyzettel a válaszadók többsége ezeken a területeken tisztában volt, mert az értékek inkább az alacsonyabb intervallumban szóródtak.

Összességében az info-kommunikációs hozzáférési index és a szubjektív regionális attitüdök hasonló képet, egy - a főváros erös hatása melletti - nyugat-kelet irányú digitális szakadék lejtôt rajzolnak ki ( 1 . táblázat).

Érdemes megemlítenünk, hogy a már idézett prominencia kutatásban a dél-alföldi és az észak-alföldi válaszadók más regionális válaszadókhoz képest sokkal jobban bíztak abban, hogy az információs társadalom fejlesztésének lehet szerepe a területi fejlödés felgyorsításában, és válaszaikból is az tükrözödött, hogy az információs társadalom fejlesztése hozzájárul a területi különbségek csökkentéséhez. Vélhetően a keleti területek információs társadalommal kapcsolatos „optimizmusa” a hagyományos kitörési utak, a modernizációs lehetőségek válságával van összefüggésben. Értékelésünk szerint mindez az átmenet évtizedében jellemző általános értékvesztett (,anómiás”) állapotokkal és azzal a társadalmi ténnyel lehet összefüggésben, ami a közbeszédben úgy jelenik meg, hogy - az Európai Unió perifériáján - hazánk számá$\mathrm{ra}^{25}$ (Írországhoz hasonlóan) kiugrási lehetőséget teremthet az információs korszak.

\section{Roma résztársadalmi csoportok a digitális szakadékban ${ }^{26}$}

A digitális kultúra meggyökeresítése esélyeinek vizsgálata a leszakadó társadalmi csoportok körében az első országos földprogramos társadalom és településvizsgálat (Szoboszlai Zsolt és munkatársai, 2003) során merült fel. A felmérés folytatását egyrészt a szociális földprogramban részt vevő roma kedvezményezettek közel 50\%-os aránya, valamint a digitális egyenlőtlenségek és a területi periféria hatékonyabb feltérképezése (Csatári és munkatársai, 2003), valamint a társadalompolitikák körében az esélyegyenlöség elvének (Európában és hazánkban is egyre növekvö) hangsúlya indokolta. Mindez azért fontos, mert a magyarországi cigányság lakóhelye jórészt egybeesik a belső periféria jellemzỏkkel (infrastruktúra hiányosságai, a tőkehiány, a centrumoktól való nagy távolság - a magárahagyatottság, anómia érzése -, az érdekérvényesítés, valamint a humán eröforrás gyengesége) bíró földrajzi területekkel (Szoboszlai 2003a).

Úgy gondoljuk, hogy a roma társadalom szociális kirekesztettsége az informatikai kultúra terjedését is gátolja, tovább növelve ezzel a (hagyományos és digitális egyenlötlenségekben mérhetö) szakadékot és a társadalmi konfliktus lehetőségeit a makrotársadalom és hazánk legnagyobb etnikai közössége között.

Tavaly végzett felmérésünkben mintánk közel egytizede vállalkozott arra, hogy véleményt, asszociációt mondjon az információs társadalom fogalmáról.

A nyitott kérdések tartalmi elemzése során három meghatározó típust tudtunk elkülöníteni ${ }^{27}$. Egyrészt fel tudtunk állítani egy befogadó, nyitott jellemzöket takaró, alapvetően hasznos kategóriát, egy technikai orientációt jelentő változót és egy 
negatív beállítódást, elutasítást tükröző dimenziót. Jelen munka szempontjából részletesebben a befogadó és az elutasító attitüdökre fókuszálunk.

\section{„Nincs benne a romaság"}

A negatív vélemények közé soroltuk a digitális egyenlötlenségek bármely tartalmi megjelenését. Így a válaszok között megjelent a különbség társadalmi csoportok és területek között. A gondolatok között a roma társadalmi csoportra jellemzö sztereotípiákat is találunk. Néhány válaszadó ezzel kapcsolatban úgy vélte, hogy az információs társadalom témakörébe sorolható a közösségi érdekképviselet (,,nemigen tudunk politizálni"), illetve a vidéki roma élet fö problémája, a segélyezés is (,,egyre rosszabb, nem adnak segélyt, nem törödnek velünk”, illetve a „, a cigányság teljes elnyomásban él").

„Ki vagyunk belöle hagyva” - erösítik meg mások is a kirekesztettséget (,,Nem ez jut el, nem ez az elsődleges beszéd körünkben”), amit inkább egyéni indokkal magyaráznak ${ }^{28}$.

Az információs társadalommal kapcsolatos habitust jól jellemzi a közös nyelv, kulturális tőke hiánya, amit nagyon plasztikusan jelenített meg az a hozzászólás is, amely szerint az információs társadalomban az érvényesül, aki „tájékozódni tud a tv-böl", illetve ,"ért a számítógéphez".

Az elutasító választípusok másik részéhez tartozik az információdömping feldolgozhatatlanságából adódó stressz, félelem (,egyre több információ éri az embereket, már nem tudnak mit kezdeni vele").

$\mathrm{Az}$ idézetek (amelyek gondolatilag megegyeznek a szociális földprogram kedvezményezettjei által felvetettekkel - Szarvák 2003b) a mediatizált világgal, a globális változásokhoz (vizsgálatunkban az információs társadalomhoz) kapcsolható értékkel szembeni morális pánik kialakulását szemléltetik. A morális pánik léte veszélyezteti a társadalmi csoportok stabil jövőképének kialakulását, veszélyezteti valóságképüket (Kitzinger 2000). Különösen igaz ez az ún. kockázati társadalomban élö, mentális, képzettségi, kapcsolati és anyagi tőkével, stratégiával nem rendelkezỏ társadalmi csoportokra, amelyek értékvilága (előbb-utóbb) a marginalizált léthez ${ }^{29}$ lesz hasonló.

Ezzel szemben a közbeszédben már meggyökereződtek az információs társadalom előnyei és az információs kor által támasztott követelmények. Így ez az újabb leszakadás-élmény csak erősítheti ezen csoportok kirekesztettség tudatát. Ezt a kategóriát jól reprezentálja a ,nem tudom mit mond, de nem is érdekel” válasz.

\section{„,Kevesebb idö, könnyebb élet”}

A befogadó, a (technikai) modernizációra, a globális hatásokra nyitott választípusok között általában a több ismeret, az egyszerü(bb) és szabad(abb) kommunikáció, az információáramlás fejlesztő hatással van a társadalom minden rétegére. A pozitiv attitüdöket jelentő válaszok között a leggyakrabban a ,jövő”, a „fiatalság” és a „munkahelyteremtés” szó fordult elő adatfelvételünkben. Mindez annak lehet a 
jele, hogy az informatikai kultúra helyet követel magának a roma családok szocializációjában is.

A válaszadóknak az információs társadalom fogalmának hallatán - a települések tradicionális kommunikációs viszonyainak és az egyéni tömegkommunikációs fogyasztásnak köszönhetően - sokkal inkább a televízió, illetve (a kilencvenes évek területi és technológiai fejlesztésének köszönhetően) a (mobil)telefon ,ugrott be", sőt sokan említették a Gutenberg-galaxis hagyományos nyomtatott termékeit is.

Érdekes dimenzió, hogy a hálózatiság elve (az információs társadalom müködésének komplexebb megjelenése) alig köszön vissza a véleményekböl. A technikai eszközök közül az internet említése alacsony. A válaszokban nem olvashattunk a használat (e-mail, online vásárlás stb.) formájáról sem.

Összességében a válaszadók közel fele említett valamilyen technikai eszközt, a befogadó álláspont közel negyven, az elutasítás $15 \%$-ukat jellemzi. Mindezt 100 fokozatú skálán ábrázolva ( 63 pont) azt láthatjuk, hogy a válaszadók inkább pozitívan viszonyultak az információs társadalom jelentette innovációk befogadásához ${ }^{30}$.

A skála átlagait figyelve a kategóriák közötti különbség a regionális szintek (az észak-magyarországi válaszadóknak inkább pozitív, a nyugat-dunántúliaknak inkább negatîv attitüdjeik voltak az információs társadalommal kapcsolatban) között fedezhető fel.

\section{Az info-kommunikációs technika elterjedése, használatának jellemzői a roma társadalmi csoportokban}

Roma válaszadóink kilenc százaléka használta már a számítógépet, az internethasználat azonban statisztikailag elenyésző. 2003 tavaszán a vidéki roma háztartások összesen 3 százalékában volt számítógép és egy százalékában Internet ${ }^{31}$. A válaszadók közül alig $8 \%$ költene info-kommunikációs eszközökre ${ }^{33}$.

Úgy gondoljuk, hogy adataink hasonlósága azt feltételezi, hogy a roma társadaIom szociális kirekesztettsége az informatikai kultúra terjedését is gátolja, tovább növelve ezzel a (hagyományos és digitális egyenlötlenségekben mérhetö) szakadékot a makrotársadalom és hazánk legnagyobb etnikai közössége között.

Azon roma válaszadóink, akik tudják a gépet használni, fóként egyénileg, könyvekböl, vagy különböző oktatási keretek között tanulták azt meg. Az informatikai kultúra terjedésére utal az a tény, hogy a gyermekek és rokonok említése is viszonylag jelentős. A válaszadók közül leginkább az alföldi alminta járt számítástechnikai szakkörre általános iskolában. A megkérdezettek gyermekei már nagyobb eséllyel vesznek/vehetnek részt informatikai képzésen a közoktatás első nyolc évében.

Akinek van számítógépe, leginkább azért vásárolta, mert az a gyermekeknek segítség az iskolai feladatokhoz. Akinek nincs, leginkább azért nem vett még eddig gépet, mert drága. Minden negyedik válaszadót azonban nem érdekel a számítógép, minden hetedik válaszadó nem tudja használni a gépet, ezért nem költ ilyen eszközre. Hasonló okokat találtunk az internet esetében is a ,nem használatra” (1. ábra). 


\section{1. ÁBRA}

Miért nincs otthoni internetcsatlakozása a roma társadalmi csoportoknak? (\%)

(Why don't Roma Social Groups Have InternetA in their Homes?)

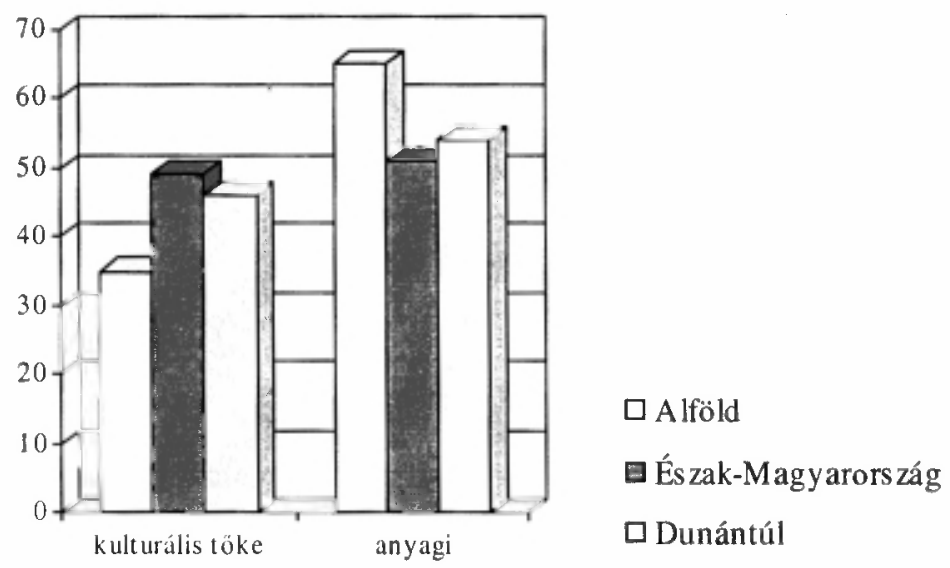

Kulturális töke-változó: nem érdekli, fél a technikától, nem tudja használni kategóriák összessége. Anyagi változó: túl drága. kisteljesítményŭ a gépe kategóriák összessége.

Forrás: A vidéki Magyarországot érintő roma résztársadalmi kutatás 2003.

A roma megkérdezetteink kétharmada nem tudna élni a foglalkoztatás új útjaival, mert nem tudja használni a távmunka egyik eszkőzét, a számítógépet. A válaszadók harmada azonban képesnek érzi magát arra, hogy megtanulja a számítógép kezelését. Öt százalék említette azt, hogy közösségben számítógépes munkát végezne, és hat százalék tudja jelenleg is alkalmazni ezt az informatikai eszközt. A válaszadók közel fele (leginkább az Alföldön) véli úgy, hogy távmunka típusú foglalkoztatásra lenne igény a településen.

A megkérdezettek többsége bízik abban, hogy az információs társadalom egyaránt előnyös lesz lakóhelyének, az országnak és a válaszadónak. Az alföldi válaszadók inkább a lakóhely és az egyén, a dunántúliak föként az ország elönyszerzésében bíznak az információs társadalom meggyökeresítése során. Ellentétben a földprogramos válaszadókkal, a roma országos mintában nagyon kevesen választották a „nem lesz hatása” kategóriát.

A megkérdezettek túlnyomó többsége úgy gondolta, hogy az államnak minden segítséget meg kell adnia, hogy az emberek könnyebben tudjanak csatlakozni az információs társadalomhoz. Az egyéni felelősség, a képzettség, a tudás megszerzése a második legfontosabb az információs társadalomban.

A minta mindezek mellett úgy véli, hogy az emberek zömének nehéz lesz csatlakozni az információs társadalomhoz. A legnagyobb területi szórást a „nincs sok értelme csatlakozni az információs társadalomhoz, mert munkaalkalmat nem teremt" válasz minósítése jelentette. A megkérdezettek összességében nem fogadták el ezt az állítást, ám Észak-Magyarországon támogatták ezt a nézetet. 


\section{Összegzés}

Az info-kommunikációs eszközök hazai penetrációja elgondolásunk szerint - vállalva a fogalom használatából adódó leegyszerüsítéseket - még indokolja a digitális szakadék dichotómia használatát. Mindez leginkább társadalompolitikai szempontból fontos, mert a digitális szakadék jelentéstartalmából adódóan a társadalmi és a területi konfliktusok lehetséges információs kori jellemzőjére mutat rá, és rávilágít arra, hogy a leszakadó területek és társadalmi csoportok számára induljanak a helyi igényeknek megfelelő digitális e-esélyegyenlőség politikák.

A jelenlegi digitális szakadék lejtő összefüggésben van a helyi társadalmak és területek hagyományos egyenlötlenségi mutatóival, így kimutatható az, hogy a terjedési folyamatok elérik a hátrányosabb helyzetü területeket és társadalmi csoportokat is, de az információs társadalom korszakában is létező verseny tovább növeli a különbségeket.

A digitális szakadék-indexek jól jelzik azt a társadalmi-területi folyamatokban gyökerező elterjedési szintet, amellyel (a használat és az elterjedtség szempontjából) megfelelően jellemezhető egy területi-társadalmi egység információs társadalom felkészültsége.

Természetesen az indexkészítéskor szembekerülünk azzal a problémával, hogy mérőszámunk milyen jelenségeket takar el. Elfogadva azt a tényt, hogy a technológia észrevétlenül egyre mélyebben beágyazódik a mindennapjainkba, ami egy rejtỏzködő információs társadalmat hoz létre (Pintér 2003), fontosnak tartjuk azt, hogy az indexkészítés alkalmával olyan változókat is bevonhassunk, amelyekben nem csak az informatikai kultúra klasszikus meghatározására koncentrálunk.

A mérőszámok fejlesztéséhez kapcsolódva javasoljuk a digitális lejtő pontosabb rögzítésére ${ }^{34}$ az európai SIBIS felmérésekhez hasonló módszerek bevezetését, vagyis véleményünk szerint a hét hazai régiót önálló területi és társadalmi entitásnak véve, regionális szintre fókuszálva kell feltérképezni az informatikai kultúrát.

\section{Jegyzetek}

'A tanulmány a Csatári Bálint által vezetett, Területi konfliktusok és változásaik a periférián címú kutatási program keretén belül készült 2003-ban.

${ }^{2}$ Dessewffy Tibor egy 2001 -es elöadásában így aposztrofálta az információs társadalom alapú fejlődést.

${ }^{3}$ Néhány értékpár a ,digitális szakadékból”" (Szarvák 2003a):

- Technológia szegények \& Technológia gazdagok

- Tudás szegények \& Tudás gazdagok

- Valódi hozzáférés \& Formális hozzáférés.

${ }^{4}$ Az információs társadalom fejlesztések egyik alapvetỏ célja éppen a lemaradások, a különbségek csökkentése személyek, közösségek és térségek között.

${ }^{5}$ Clinton irányítása alatt született meg a Mandate for Change (Felhatalmazás a változásra) címet viselö dokumentum, amelyben a Harmadik Út centrális fogalmai és szótárának legfontosabb elemei már megjelentek:

- Ứj Gazdaság. Témák: globalizáció, információs, tudásalapú társadalom, innováció, rugalmasság. 
- Új Szociológia. Témák: a társadalomban meglévő polarizációs tendenciák, új közép és új szegénység, kirekesztés és befogadás, a hagyományos struktúrák, miliök, életmódok, a családi élet átalakulása, a nők új szerepe (G. Márkus én.)

6

7

http://www.infotars.hu/docs/ITP-3kozossegi.doc

${ }^{8}$ Az EU a 2010-ig tartó évtizedet a szociális kirekesztődés, az eröszak és a szegénység elleni küzdelemnek szentelte. Az elindított programoknak a lényege az esélyteremtés, az esélyegyenlöség és a társadalomba való beilleszkedés elösegítése (Béres 2003).

${ }^{9}$ Tobias Hüsing az Európai Uniós tagjelölt és a tagországokra vonatkoztatott digitális szakadék indexében (Statistical Indicators Benchmarking the Information Society [SIBIS] a nemre, az 50 éves vagy idősebb demográfiai csoportra, a formális (alacsony) iskolai végzettségre és a jövedelemre koncentrál (Hüsing 2003).

10

Elhangzott a Szociológiai Târsaság 2002-es konferenciáján megrendezett digitális szakadék szekcióban 2002. december 12-én.

"1 Rodriguez-Wilson (2002)

${ }^{12}$ Az Informatikai és Hírközlési Minisztérium legutóbb eibírált pályázatának az volt a célja, hogy növelje a szélessávú internet-penetrációt a kisebb, jelenleg még kevésbé ellátott és üzletileg kevésbé vonzó településeken, ahol a szélessávú szolgảlttatás nyújtásához szükséges infrastruktúra állami támogatás hiányában csak késöbb, vagy egyáltalán nem épülne ki. A pályázatban összesen 35 pályázó részesül $900043000 \mathrm{Ft}$ támogatásban (http://www.ihm.hu/palyazatok/palyazatok 20031211 1.html).

13

Különösen fontosak a társadalmi bekapcsolódást növelö, esélyteremtő programok az Információs Társadalomban, ahol az innováció olyan gyors, hogy szinte mindig åtugrunk egy technikai lépesöt, és nincs időnk teljesen leamortizálni egy iparágat.

14

Ezzel magyarázható az a projekt, amely a német információs társadalom program (Internet für-alle) része: a szövetségi munkaügyi hivatal a netes ismeretek nélküli munkanélkülieknek biztosítja, hogy ingyenes ,internetes jogosítvânyt” szerezzenek. A résztvevők új lehetöséget kapnak, hogy mélyítsék a gyakorlatban is ismereteiket. Ezzel esélyeik is nönek egy új állás megtalálására (Initiative... 2003).

${ }^{15}$ A fejezet Tobias Hüsing: Zuhnemendes Nord-Süd Gefälle der digitalen Spaltung in der EU. (2003) címủ tanulmánya alapján készültt.

${ }^{16}$ Az adatok az 1997-es és a 2000-es Eurobarométer, valamint a 2002-es és a 2003-as SIBIS kérdöíves felmérés eredményein alapulnak. 2003-ban az EU tagjelölt országok is bekapcsolódtak a felmérésbe. A vizsgált társadalmi változók: nők, 50 év feletti életkor, alacsony (formális) iskolai végzettség és az alacsony jövedelem.

${ }^{17}$ Mivel a diffúzió folyamatát számos kategória határozza meg: többek között önmagunk fejlesztése (pí. használati szokások, tudások), a társadalmi struktúra (pl. a szociális háló és miliö összefonódása), a nyilvános kommunikáció (tömegkommunikáció, marketing) jellemzői. Megállapítható, hogy az infokommunikációs használat összeadódott gyakorisága növekszik, és egy $\mathrm{S}$ görbét vesz fel.

${ }^{18} \mathrm{Az}$ indexkészítés során az info-kommunikációs változókból egy PC és Internet-használati indexértéket képeztek, amit otthoni és általános Internet-használatra bontottak.

${ }^{19}$ Az Internet-használók aránya az 1997-es felméréskezdettől az EU lakosság 7\%-áról a 2000-es évre 26\%-ra, 2002-re 50\% fölé emelkedett. A számítógép használatnál az emelkedés mérsékeltebb volt (36\%-ról 57\%-ra nött ez az adat).

${ }^{20}$ Az országok említése az indexben elért sorrendet követi.

${ }^{21}$ Kanalas (2003) által megállapított megyei típusok:

1) Az információs társadalom kialakuló „magterületei” (Baranya, Budapest, Csongrád, Győr-MosonSopron, Pest)

2) Információs-kommunikációs szempontból „felzárkózơ” területek (Bács-Kiskun, Fejér, HajdúBihar, Veszprém, Zala)

3) Az információs fejlỏdésre „várakozók” (Békés, Borsod-Abaúj-Zemplén, Heves, KomáromEsztergom, Vas)

4) Információs szempontból „hátrányos helyzetü” területek (Jász-Nagykun-Szolnok, Nógrád, Somogy, Szaboles-Szatmár-Bereg, Tolna). 
22 országos reprezentatív felmérésből (2001) kiderül, hogy az internetezök között a férfiak, a Budapesten, illetve a megyeszékhelyeken élök, a 30 év alattiak, a tanulók és gazdaságilag aktívak vannak többségben. Közöttük nagyobb arányban találhatóak érettségizettek vagy felsőfokú végzettséggel rendelkezök.

A 2001-es kutatási jelentés a területi hátrányokat települési szinthez köti: a budapestiek $44 \%$-a használ számítógépet és $26 \%$-a internetet, a községekben élőknél ezek az arányok csak $21 \%$-ot, ill. 11\%-ot tesznek ki. A megyeszékhelyeken élők körében a számítógép- és internet-használat aránya a budapestihez âll közelebb (41\% a számítógép-, 24\% az internet-használók aránya), míg az egyéb városokban élők között az arány inkább a községekben élökhöz áll közel (29\%, ill. 16\%) (Rigler én.).

23 Érdemes megemlítenünk, hogy az ezen index alapján történt területi csoportosítás számos esetben megfeleltethetö Kanalas Imre KSH adatokon létrehozott tipológiájának.

${ }^{24}$ A prominencia latin kifejezés, fỏnévként valaminek a kiemelkedését (esetünkben bizonyos társadalmi csoportokét) jelenti. Így értelmezésünkben a prominencia a lokális társadalmi (foglalkoztatási) hierarchia csúcsán elhelyezke dó (szakértói) csoportot jelenti (Andorka 1997).

A prominencia vizsgálatok módszertana lényegében hasonló a különbözỏ célcsoport-felmérésekéhez, amikor nem a "tömegközönséget" vizsgáljuk, hanem a piramis csúcsán lévő vezetőket és a „,vélemény-elitet" (Angelusz 1983), mert az a hipotézisünk, hogy egy-egy társadalom vagy térség innovációjának, fejlódésének kulcsemberei az adott társadalmi csoport vagy térség, illetve a fontosabb települések prominens személyiségei.

25 Így országunk leszakadó területei számára is.

${ }^{26}$ A vidéki (nem budapesti) Magyarországot érintỏ roma résztársadalmi kutatásra 2003-ban került sor. A megkérdezett személyek száma közel ezer (983) fö volt.

${ }^{27}$ A nyitott kérdések válaszaiból egy információs társadalom befogadás-skálát konstruáltunk. A skála 100-as értéke az információs társadalommal kapcsolatos bármilyen pozitív attitüdöt, a 0 pedig a különbözỏ negatív beállítódásokat jelenti. A skála 50-es értékéhez soroltuk a semleges viszonyulást. Elfogadva a következő definíciót: a technológia fogalma az ember és gép, gép és piac, ember és társadalom közötti komplex kapcsolatrendszert jelöli, úgy véltük, hogy a technikai eszkőzók ismeretéböl nem következtethetünk a válaszadó információs társadalommal kapcsolatos beállítódásaira, ezért a skála 50-es értékéhez soroltuk a semleges viszonyulást, a technikai info-kommunikációs eszközök említéseit.

Másként fogalmazva: a százfokozatú skálán a 100-as érték az információs társadalom (okozta változások) befogadását, a 0 érték az elutasítását jelentette.

28

A szociális földprogramos válaszadók körében erösebben érzödtek a települési különbségek, és az elutasítás központi fogalmi köre a ,nem ismerem én a városi nyelvet" gondolat köré szerveződött.

${ }^{29}$ Felmérésünkben mindkét identifikációs csoportban a munkanélküliség, a pénztelenség, alacsony keresetek és a szegénység, létbizonytalanság volt a legnagyobb probléma.

${ }^{30}$ Fontos megjegyeznünk, hogy a kérdésre 143 megkérdezett válaszolt. Ez az elemszám a teljes mintához (N=1069) viszonyítva eléggé alacsony (13\%), ami újra felhívja a figyelmet a vizsgált társadalmi csoportok információs kori kirekesztettségére.

${ }^{31}$ Legalább egy személyi számítógép található a magyarországi háztartások kevéssel tởbb mint ötơdében (22\%), s a hâztartások 3 százalékában egynél több személyi számítógép is múködik ( $A$ magyar lakosság... 2001).

Egy másik összehasonlítható adat: a földprogramos roma résztvevök 3, a nem roma kedvezményezettek $9 \%$-ának van otthon számítógépe.

${ }^{32}$ Öt százalék költene számítógépre, három százalék Internetre egy éven belüi.

${ }^{33}$ Megjegyezzük, hogy azok, akik bíznak az információs társadalomban, inkább szándékoznak költeni info-kommunikációs beruházásokra.

${ }^{34}$ Ami természetesen felhasználható lenne a készullö regionális információs társadalom stratégiák helyzetelemzéséhez, illetve majdani aktualizálásához is. 


\section{Irodalom}

Andorka R. (1997) Bevezetés a szociológiába. Aula Kiadó, Budapest.

Angelusz R. (1983) A kommunikáló társadalom. Gondolat, Budapest.

Béres Cs. (2003) Tervezet a Hajdú-Bihar megyei Esélyek Háza létrehozására. Kézirat. Hajdú-Bihar Megyei Önkormányzat, Debrecen.

Böhm A. (1999) XX. századi magyar társadalom. Korona Kiadó, Budapest.

Castells, M. (1996) Új társadalom. http://www.inco.hu/inco7/kitekint/cikk0h.htm

Csanády A. (1994) Az átalakulás határai. - Balogh I. (szerk.) Törésvonalak és értékválasztások. MTA

Politikai Tudományok Intézete, Budapest.

Csepeli Gy. (2002) E-polis. http://www.ihm.hu/informacio/hirarchivum/publikaciok/epolis 20020813.html

Dányi E.--Dessewffy T. (2002) Digitális szakadék mint akarat és képzet, avagy Manchester Zalaegerszegre megy. Előadás rezümé. Magyar Szociológiai Társaság konferenciája, 2002. december 13. Budapest.

Dessewffy T. (2002) A kocka el van veszve. Információs Társadalom Szakkönyvtár-Aula, Budapest.

Dessewffy T.-Fábián Z. (2002) A digitális jövö térképe. A magyar lakosság és az Internet. ITTKTÁRKI, Budapest.

Dessewffy T.-Z. Karvalics L. (2002) Az Új törvénykönyv. Internet, technológia, társadalom. - Kritika. Január. 2-5. o.

DiMaggió, P.-Hargittai, E. (2002) „From the „Digital Divide” to „Digital Inequality”: Studying internet Use As Penetration Increases". Working Paper 19. Center for Arts and Cultural Policy Studies.

Farkas J. (2003) A társadalmi tér elméleti kérdései (a térfelfogás történeti változásai). - Társadalomkutatás. 2. 167-190. o.

Farkas J.Gy. (2001) Nagyobb bajt keserübb orvosság gyógyít. - Népszabadság. március 26.

Fábián Z. (2002) Digitális írástudás: a számítógép és az internethasználat elterjedtségének társadalmi jellemzői Magyarországon. - Kolosi T.-Tóth I.Gy.-Vukovich Gy. (szerk.) Társadalmi riport. TÁRKI, Budapest. 152-161. o.

Fukuyama, F. (2000) A nagy szétbomlás. Európa Kiadó, Budapest.

G. Márkus Gy. (én.) A „Harmadik Út" és a globális kapitalizmus megszeliditése. Identitás-dilemmák és útkeresés. www.jadat.hu/gm0001.pdf Letöltve: 2003. december 14.

György P. (1996) Az információs forradalom társadalmi hatásai. - Info-Társadalomtudomány. 38. 117-122. o.

Hüsing, T. (2003) Zuhnemendes Nord-Süd Gefälle der digitalen Spaltung in der EU. Informationsdienst Soziale Indikatoren. Ausgabe 30. Juli 2003. www.gesis.org. Letöltve: 2003. november 26.

Initiative ,Internet für-alle”. (2003) www. bundesregierung.de/servlet Letöltve: 2003. szeptember 12.

Kanalas 1. (2000) Az információs-kommunikációs technikák terjedésének regionális különbségei Magyarországon. - Tér és Társadalom. 2-3. 159-172. o.

Kanalas I. (2003) A megyék versenyképessége az információs társadalomban. - Nagy G.-Kanalas I. (szerk.) Régiók az Információs társadalomban. MTA RKK ATI, Kecskemét.

Kasvió, A. (1999) Az információs társadalom kialakulása, mint legfontosabb társadalomtudományi kutatási program. Nemzet és Stratégia Füzetek 4. HÉA Stratégiakutató Intézet, Nagykovácsi.

Kitzinger D. (2000) A morális pánik elmélete. - Replika. 40. 23-48. o.

Kolosi T. (2000) Terhes babapiskóta. Osiris, Budapest.

A magyar lakosság és az Internet. (2001) Részletes eredmények. WIP-projekt. http://www.ittk.hu/weblap/ docs/wip_full.pdf

Molnár Sz. (2002) A digitális írástudásban élenjárók és lemaradók közötti szakadék társadalompolitikai kihívásai napjainkban. A digitális megosztottság értelmezési kerete. - Információs Társadalom. 4. 82-101. o.

Norris, P. (2001) Digital Divide? Civic Engagement, Informatin Poverty and the Internet in Democratic Societies. Cambridge University Press, New York.

Pokol B. (1988) A szociológiaelmélet új útjai. Akadémiai Könyvkiadó, Budapest.

Pintér R. (2003) Magyarország - a rejtözködö információs társadalom tézise. - eVilág. Október. 4-8. o.

Rigler A. (én.) Jelentösek a különbségek a különbözö társadalmi csoportok internet-használata között. http://www.ittk.hu/weblap/docs/wip_jelentoskulonbsegek.pdf

Rigler A. (2002) A digitális szakadék tágulásának modellje. Elỏadás rezümé. Magyar Szociológiai Társaság konferenciája, 2002. december 13. Budapest.

Rodriguez, F.-Wilson, E.J. (2002) Are Poor Countries Losing the Information Revolution? www.bridges.org 
Szarvák T. (2001) Régiók az információs társadalomban. MTA RKK ATI Szolnoki Társadalomkutató Csoport, Szolnok. Kézirat.

Szarvák T. (2003a) Beszámoló a digitális kihívás konferenciáról. MTA RKK ATI Szolnoki Társadalomkutató Csoport, Szolnok. Kézirat.

Szarvák T. (2003b) A későn jövők hátránya. A digitális forradalom jellemzöi a földprogramos kedvezményezettek körében. - Szoboszlai Zs. (szerk.) Cigányok a szociális földprogramban. Gondolat, Budapest. 97-114. o.

Szarvák T.-Szoboszlai Zs. (2003) Humán erőforrások egy alfơldi megyeszékhelyen. - eVilág. Március. 11-16. 0 .

Szoboszlai Zs. (2003a) A szociális földprogram roma kedvezményezettjeinek társadalmi jellemzői. Szoboszlai Zs. (szerk.) Cigányok a szociális földprogramban. Gondolat Kiadó, Budapest, 31-79. 0.

Szoboszlai Zs. (szerk.) (2003b) Cigányok a szociális földprogramban. Gondolat, Budapest.

Tamás P. (én.) A harmadik út vége - a jóléti állam jövője. Elöadás.

Terủleti konfliktusok és változásaik a periférián. (2003) Témavezetö: Csatári B., MTA RKK ATI, Kecskemét. Kézirat.

Varga Cs. (1999) Kérdésfelvetés avagy a lokalizáció-minimum. Harmadik Évezred Alapítvány, Stratégiakutató Intézet, Budapest. Kézirat.

Zapf, W. (2002a) A társadalmi innovációkról. - Spéder Zs. (szerk.) Modernizáció, jólét, atmenet. Andorka Rudolf Társadalomtudományi Társaság-Századvég, Budapest. 31-55. o.

Zapf, W. (2002b) Modernizáció és modernizációelméletek. - Spéder Zs. (szerk.) Modernizáció, jólét, átmenet. Andorka Rudolf Társadalomtudományi Társaság-Századvég, Budapest. 71-92. o.

Z. Karvalics L. (2002) Az információs társadalom keresése. Információs Társadalom szakkönyvtárAula, Budapest.

http://www.ittk.hu/weblap/docs/wip_full.pdf World Internet Projekt teljes anyag

http://www.ihm.hu/palyazatok/palyazatok_20031211_l.html IHM pályázati eredmények

http://www.infotars.hu/docs/ITP-3kozossegi.doc HM pályázatok

\section{THE DIGITAL GAP, AS A NEW PHENOMENON RESPONSIBLE FOR HAVING PERIPHERIES TIBOR SZARVÁK}

On the base of theoretical and empirical results the study analyses the social inequalities and the concept of the digital gap, which exist as a result of the development of information society. The actuality of this matter is that the social and digital slope can be conceived as a rebirth of previous inequalities in our century. In the analysis we embark on examining the attitudes and role set of Roma people towards information society.

On the base of a survey carried out with Roma social groups, we urge equal opportunities programs - referring to local needs - for excluded people on the peripheries. 